\title{
Effect of Streptoverticillium cinnamoneum Cell Wall on Staphylococcus aureus Infection in Mice
}

\author{
Yoshio Okawa, Kazuhiko Hashimoto, Tatsuji Matsumoto, \\ Shigeo Suzukr, and Masuko Suzuki \\ Tohoku College of Pharmacy, Komatsushima, 4-4-1, Sendai 983, Japan
}

(Received August 21, 1981)

\begin{abstract}
A cell wall fraction of Streptoverticillium cinnamoneum, a non-pathogenic strain of Streptomycetaceae, was obtained by centrifugation of sonicated mycelia. After treatment with proteases, deoxyribonuclease, ribonuclease, and organic solvent mixture, the cell wall specimen (P-CW) was found to consist of homogeneous fibrous material when examined under an electron microscope. The survival of mice in the infection-protection assay against the Staphylococcus aureus $\beta \mathrm{H} 248$ strain, $1.5 \times 10^{9}$ cells/mouse, was increased by treatment with $50 \mathrm{mg} / \mathrm{kg}$ of P-CW as compared with the control group. Remarkable elevation of serum lysozyme and carbon clearance activities was observed in mice treated with the same dose of P-CW.
\end{abstract}

Keywords_-Streptoverticillium; cell wall; Staphylococcus aureus; infection; protection; serum lysozyme; phagocytic activity

It is well-known that higher animals have many defense mechanisms against bacterial infection, and that the role of macrophages is quite important in these host-defense mechanisms. Lysozyme, a secretory product of the macrophage-monocyte series, ${ }^{1)}$ was found to be a strong bacteriolytic factor, also modulating antitumor and phagocytic activities of the same host animal.2) Serum lysozyme has been considered as an index of the state of macrophage. ${ }^{3)}$. It is also well-known that some microorganisms ${ }^{4)}$ and cell wall components ${ }^{4 b, 5)}$ are able to enhance nonspecific resistance to bacterial infections, with accompanying elevation of lysozyme activity.

Recently, we reported the antitumor effect of a cell wall fraction of a non-pathogenic species of Streptomycetaceae, Stv. cinnamoneum, against mice implanted with Ehrlich and Meth-A ascites tumors. ${ }^{6)}$ In order to examine whether this cell wall fraction is also capable of protecting against bacterial infection, a series of infection-defense assays has been carried out in mice challenged with a virulent strain of Staphylococcus aureus. The present paper reports the anti-Staphylococcal activity of the cell wall of Stv. cinnamoneum with special reference to the modulation of serum lysozyme and carbon clearance activities.

\section{Experimental}

Materials-Streptoverticillium (Stv.) cinnamoneum IFO 12852 was used throughout. Lyophilized Mycobacterium bovis was obtained from the Japan BCG Laboratory Ltd., Tokyo, Japan. Male ddY mice, $22 \pm 2 \mathrm{~g}$, were used.

Preparation of Cell Wall_- The Stv cinnamoneum IFO 12852 strain was cultured as described previously." The cell wall was prepared according to the method of Nakamura et al. ${ }^{8}$ and was further purified by the following procedures. A suspension of the cell wall, $320 \mathrm{mg}$ in $100 \mathrm{ml}$ of $0.1 \mathrm{M}$ Tris-HCl buffer, $\mathrm{pH} 7.5$, containing $20 \mathrm{mg}$ each of trypsin and chymotrypsin, was gently stirred at $37^{\circ} \mathrm{C}$ for $15 \mathrm{~h}$ and washed once with the same buffer. The trypsin-chymotrypsin treatment was repeated twice, and the residue was resuspended in the same buffer, $100 \mathrm{ml}$, containing pronase, $20 \mathrm{mg}$. After incubation at $37^{\circ} \mathrm{C}$ for $15 \mathrm{~h}$, the solid mass was centrifuged and washed with the buffer. Then it was suspended in $100 \mathrm{ml}$ of the buffer containing $10 \mathrm{mg}$ each of deoxyribonuclease and ribonuclease, and the mixture was kept at $37^{\circ} \mathrm{C}$ for $15 \mathrm{~h}$. Then, the solid mass was extracted with a mixture of chloroform-methanol-water $(1: 1: 1, \mathrm{v} / \mathrm{v})$ by mechanical stirring at room temperature for $15 \mathrm{~min}$. After centrifugation, insoluble material suspended between water and solvent layers was collected and further extracted 3 times by the same procedure. Finally, the purified cell walls (P-CW) of the middle layer were freeze-dried. The cell wall preparations were routinely checked the shadowing method with a Hitachi type HUllDS electron microscope. 
Analytical Methods___-Total sugar was determined by the modified method of Molisch.9) Total hexosamine was determined by the modified method of Elson and Morgan. ${ }^{10)}$ Total phosphorus was quantitated by the method of Ames and Dubin.11) Amino acid analysis was conducted using a Hitachi model 835 amino acid analyzer after hydrolysis of the sample for $15 \mathrm{~h}$ at $105^{\circ} \mathrm{C}$ in $6 \mathrm{~N} \mathrm{HCl}$. Glucosamine and galactosamine were quantitated using the same amino acid analyzer after hydrolysis for $4 \mathrm{~h}$ at $105^{\circ} \mathrm{C}$ in $4 \mathrm{~N}$ $\mathrm{HCl}$. Neutral sugars were analyzed qualitatively by descending chromatography on Toyo filter paper No. 51A. ${ }^{12)}$

Treatment of Mice-Mice received intraperitoneal injections of various doses of $\mathrm{P}-\mathrm{CW}$ or $\mathrm{BCG}$ on days 6,4 and 2 before challenge with $S$. auveus, or assay of serum lysozyme and carbon clearance activities.

Infectious Challenge-Staphylococcus aureus $\beta \mathrm{H} 248$ strain was grown in Staphylococcus No. 110 medium (Nissui Seiyaku Co., Tokyo, Japan) for $43 \mathrm{~h}$ at $37^{\circ} \mathrm{C}$ and the harvested cells were suspended in saline. The cells $\left(1.5 \times 10^{9}\right)$ were injected intravenously in the tail vein of ddX mice, then the mice were observed for $60 \mathrm{~d}$.

Enzyme Activity of Serum__B Blood was drawn from the carotid, and serum was separated by centrifugation. Lysozyme activity was assayed according to Parry et al. ${ }^{13)}$ by using lyophilized cells of Micrococcus lysodeikticus (Miles Laboratories Inc., Kankakee, U.S.A.) as a substrate. The change in transmission percentage at $540 \mathrm{~nm}$ per min was recorded and compared to a standard curve prepared with known concentration of egg white lysozyme (Merck, Darmstadt, Germany).

Assay of Phagocytic Activity — The phagocytic activity of the reticuloendothelial system was examined by measuring the clearing rate of colloidal carbon in the mouse blood according to the method of Biozzi et al..$^{14)}$ The mice were injected intraperitoneally with P-CW and BCG $(50 \mathrm{mg} / \mathrm{kg})$ on days 0,2 and 4 . Phagocytic activity was measured on day 6 . The phagocytic index, $K$, was calculated according to the description in the previous paper. ${ }^{7}$

\section{Results and Discussion}

A significant decrease of the cell envelope content was observed as the purification procedure of P-CW was repeated. Finally, P-CW no longer contained electron-dense material, as shown in Fig. 1, and was therefore confirmed to consist of the so-called cell wall skeletons. From the results of chemical analyses (Table I), the components of P-CW were amino acid $(39.2 \%)$, hexosamine $(14.4 \%)$, neutral sugar $(4.9 \%)$, and phosphorus $(1.6 \%)$, on a weight basis with respect to lyophilized $\mathrm{P}-\mathrm{CW}$. Galactose and mannose were identified as the neutral sugar components of $\mathrm{P}-\mathrm{CW}$. The amino acid and amino sugar compositions ( $\mu \mathrm{mol} / \mathrm{mg}$ ) of P-CW were glutamic acid 0.58, muramic acid 0.41, glycine 0.64 , alanine 1.04 , diaminopimelic acid 0.70, glucosamine 0.59 and galactosamine 0.04 (Table II). The total amino acid and phosphorus contents of $\mathrm{P}-\mathrm{CW}$ were much higher than those of the cell wall skeletons of $\mathrm{BCG}$ and Corynebacterium, ${ }^{15)}$ whereas the neutral sugar content was less than those in the other

TABle I. Chemical Composition of P-CW from Stv. cinnamoneum

\begin{tabular}{cccc}
\hline $\begin{array}{c}\text { Total sugar } \\
(\text { as glucose }) \\
(\%)\end{array}$ & $\begin{array}{c}\text { Total } \\
\text { hexosamine } \\
(\%)\end{array}$ & $\begin{array}{c}\text { Total } \\
\text { amino acid } \\
(\%)\end{array}$ & $\begin{array}{c}\text { Total } \\
\text { phosphorus } \\
(\%)\end{array}$ \\
\hline 4.9 & 14.4 & 39.2 & 1.6 \\
\hline
\end{tabular}

These values are expressed on a weight basis of dried P-CW of Stv. cinnamonewm.

TABle II. Amino Acids and Amino Sugars in P-CW from Stv. cinnamoneum

\begin{tabular}{lcc}
\hline Amino acids and amino sugars & $\mu$ mol/mg & Molar ratio \\
\hline Glutamic acid & 0.58 & 1.00 \\
Muramic acid & 0.41 & 0.71 \\
Glycine & 0.64 & 1.10 \\
Alanine & 1.04 & 1.70 \\
Diaminopimelic acid & 0.70 & 1.21 \\
Glucosamine & 0.59 & 1.02 \\
Galactosamine & 0.04 & 0.07 \\
\hline
\end{tabular}




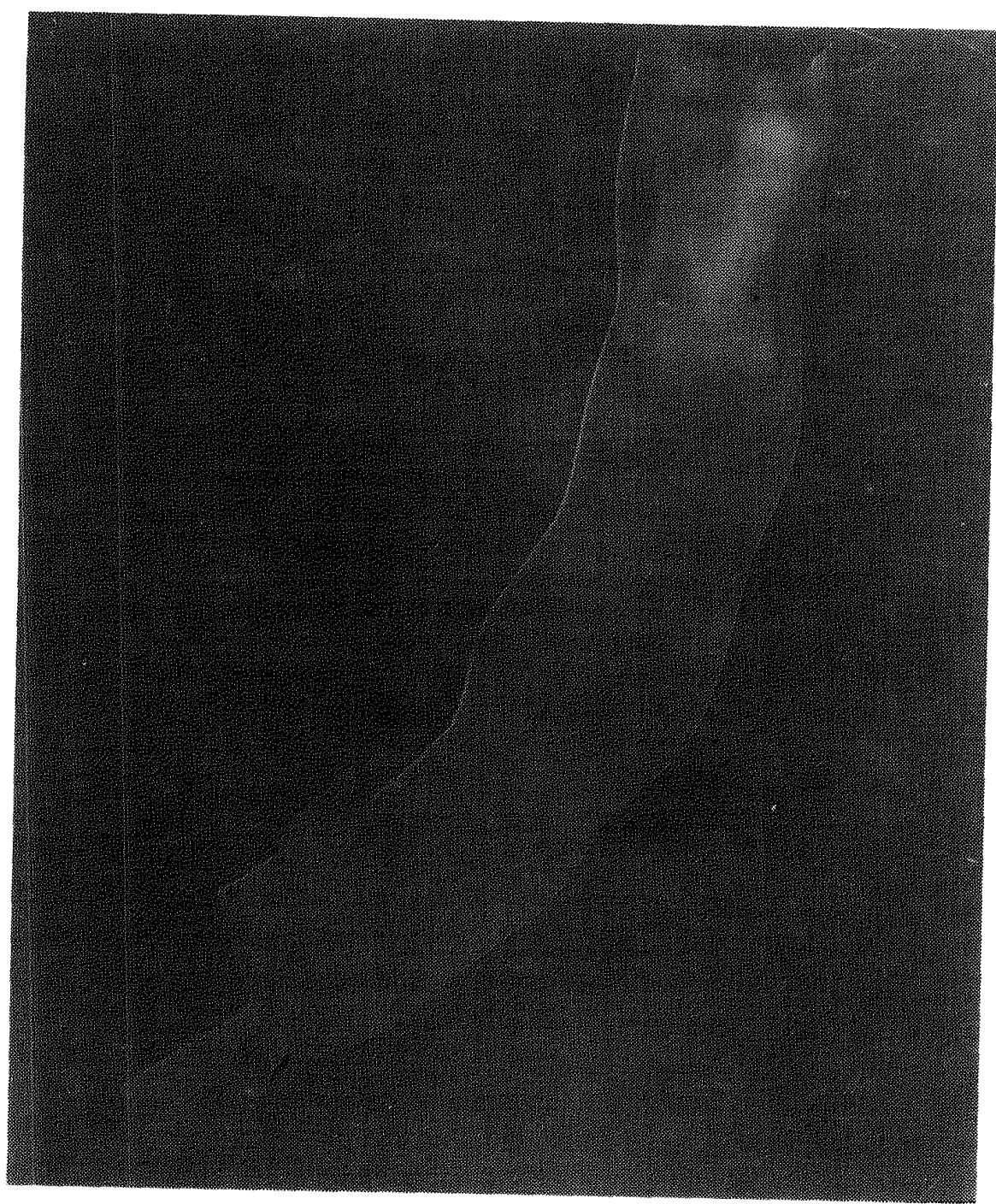

Fig. 1. Observation of P-CW from Stv. cinnamoneum by Electron Microscopy $(\times 37000)$

TABLE III. Effect of P-CW Treatment on the Survival of ddY Mice with Staphylococcus aureus Infection

\begin{tabular}{lccc}
\hline Samples & $\begin{array}{c}\text { Dose } \\
(\mathrm{mg} / \mathrm{kg} \times 3)\end{array}$ & $\begin{array}{c}\text { Mortality } \\
(\text { death/total })\end{array}$ & $\begin{array}{c}\text { Survival } \\
(\%)\end{array}$ \\
\hline Control & & $13 / 16$ & 19 \\
P-CW & 1 & $5 / 6$ & 17 \\
P-CW & 50 & $1 / 16$ & 94 \\
BCG & 50 & $5 / 16$ & 69 \\
\hline
\end{tabular}

P-CW or BCG was administered intraperitoneally on days 6,4 and 2 prior to intravenous challenge with the bacteria $\left(1.5 \times 10^{\circ}\right.$ cells per mouse). This table shows the results $60 \mathrm{~d}$ after the infections challenge.

organisms. The protecting effect of $\mathrm{P}-\mathrm{CW}$ in mice against $S$. aureus is shown in Table III. $\mathrm{P}-\mathrm{CW}$ at doses of 1 and $50 \mathrm{mg} / \mathrm{kg}$ was given to mice intraperitonally at intervals of 6,4 and $2 \mathrm{~d}$ prior to an intravenous challenge with $S$. aureus. The survival percent did not increase with $1 \mathrm{mg} / \mathrm{kg}$ of $\mathrm{P}-\mathrm{CW}$, but increased with $50 \mathrm{mg} / \mathrm{kg}$ of $\mathrm{P}-\mathrm{CW}$. Only $19 \%$ of mice in the control group survived as opposed to $94 \%$ survival in the P-CW-treated group $(p<0.01)$. Figure 2 shows the lysozyme activity of serum of ddY mice treated 3 times with $50 \mathrm{mg} / \mathrm{kg}$ of $\mathrm{P}-\mathrm{CW}$, indicating that $\mathrm{P}-\mathrm{CW}$ was able to stimulate the serum lysozyme activity. The 
curve reached a peak at $2-3 \mathrm{~d}$ after the third injection of $\mathrm{P}-\mathrm{CW}$, then the activity gradually decreased to the control level. The effect of doses of P-CW on the lysozyme activity of serum is shown in Fig. 3. Remarkable stimulation of serum lysozyme activity was seen in the mice pretreated with $50 \mathrm{mg} / \mathrm{kg}$ of $\mathrm{P}-\mathrm{CW}$, while no stimulation of this activity was seen in the mice pretreated with $1 \mathrm{mg} / \mathrm{kg}$ of $\mathrm{P}-\mathrm{CW}$, as compared with the control group. P-CW and BCG were administered intraperitoneally and intravenously on days 0,2 and 4, and serum lysozyme activity was measured on day 6 (Fig. 4). Serum lysozyme activity of mice injected with P-CW using both routes increased about 2 times as compared with the control group. However, the lysozyme activity of mice treated with BCG by intravenous injection was not elevated, though the activity slightly increased after intraperitoneal injection relative to the control group. A significant increase of carbon clearance activity was observed in mice treated with $\mathrm{P}-\mathrm{CW}$ and BCG as compared with the control group (Fig. 5).

Although the protection mechanism against microbial infection is not fully understood, participation of released lysosomal enzymes and active oxygens is considered to be very important. In a previous presentation, we reported that the lysosomal enzyme activity of peritoneal macrophages of mice increased after treatment with $\left.\mathrm{P}-\mathrm{CW},{ }^{6}\right)$ suggesting that lysozyme has an important role in the initial stages of microbial invasion. ${ }^{16)}$ It is thought that lysozyme acts as an antibacterial agent directly through its bacteriolytic action. Biggar and Sturgess have reported the significant role of lysozyme in mediating the microbicidal action of rat alveolar macrophages, ${ }^{16 a}$ ) demonstrating that phagocytosis of intact bacteria did not occur, whereas lysozyme-degraded bacteria were rapidly phagocytized. In the present paper, it is shown that serum lysozyme activity in mice increased on treatment with $\mathrm{P}-\mathrm{CW}$,

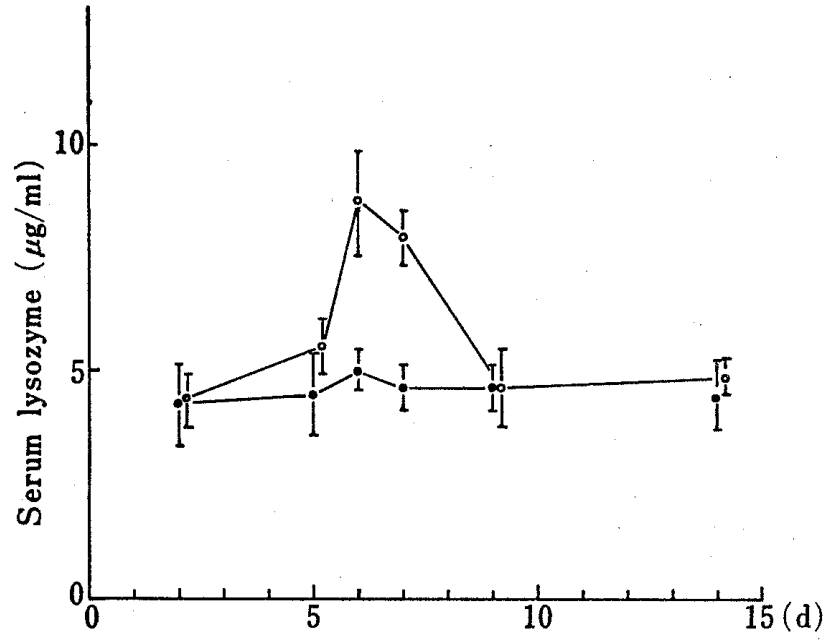

Fig. 2. Serum Lysozyme in Mice administered with $\mathrm{P}-\mathrm{CW}$

The mice were injected intraperitoneally with P-CW $(50 \mathrm{mg} / \mathrm{kg})$ on days 0,2 and 4 . The mice were examined at $2,5,6,7,9$ and 14. $\mathrm{d}$ after the beginning of $\mathrm{P}-\mathrm{CW}$ administration.

; control, O; P-CW.

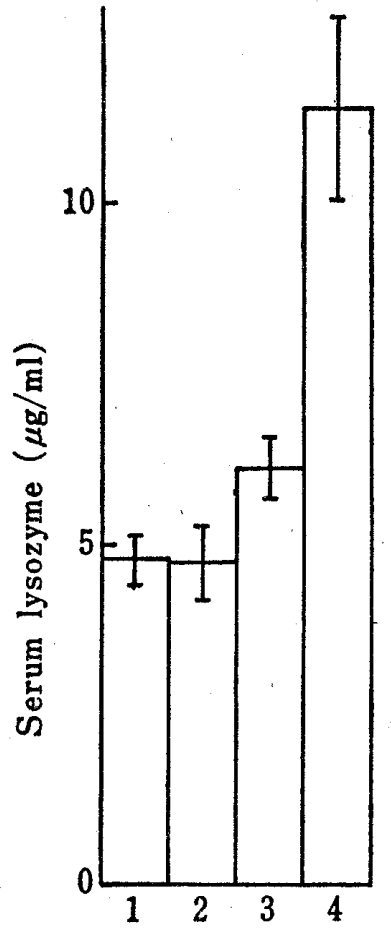

Fig. 3. Dose Response Relation for Serum Lysozyme in Mice administered with.P-CW

The mice were injected intraperitoneally with P-CW on days 0,2 and 4 . Serum lysozyme concentration was measured on day 6 .

1; control.

2; P-CW $1 \mathrm{mg} / \mathrm{kg}$.

3; P-CW $5 \mathrm{mg} / \mathrm{kg}$.

4; $\mathrm{P}-\mathrm{CW} 50 \mathrm{mg} / \mathrm{kg}$. 


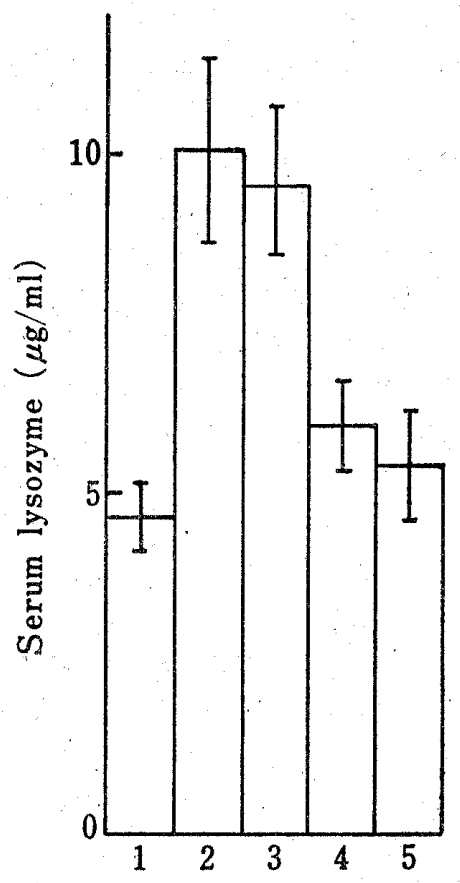

Fig. 4. Effect of Intraperitoneal and Intravenous Administrations of $\mathrm{P}-\mathrm{CW}$ and BCG on Serum Lysozyme

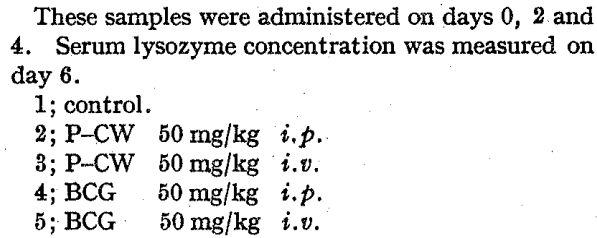

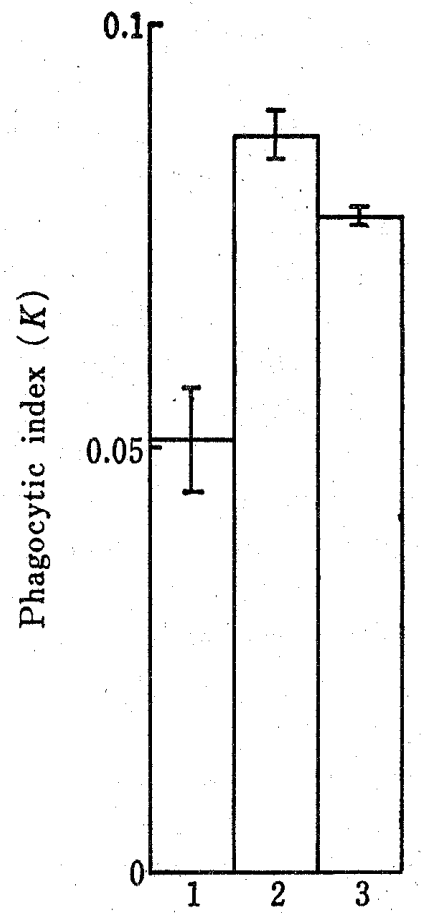

Fig. 5. Elevation of Carbon Clearance Activity of Mice administered with $\mathrm{P}$ CW and BCG

The mice were injected intraperitoneally with $\mathrm{P}$ CW and BCG on days 0,2 and 4 . Phagocytic activity was measured on day 6 .

1 ; control.

$2 ; \mathrm{P}-\mathrm{CW} 50 \mathrm{mg} / \mathrm{kg}$.

3; BCG $50 \mathrm{mg} / \mathrm{kg}$

and when the activity finally peaked (Fig. 2), the mice were challenged intravenously with $S$. aureus. As shown in Table III, treatment of mice with P-CW significantly increased their survival potential. Moreover, the increase of resistance to infection was correlated well with the increase in serum lysozyme activity induced with P-CW. Cappuccino et al. ${ }^{17}$ ) suggested that the augmentation of lysozyme activity may be the result of stimulation of the reticuloendothelial system of the host. Therefore, the carbon clearance activity of mice treated with P$\mathrm{CW}$ was examined. The activity was remarkably increased as compared with the control group (Fig. 5). Numbers of peritoneal exudate cells at this time were increased about 6-10 times over the control group. From this result, $\mathrm{P}-\mathrm{CW}$ was found to increase the number and phagocytic function of macrophages.

In view of these findings, it is considered that $\mathrm{P}-\mathrm{CW}$ contributes to the removal of foreign entities from the host animal via direct or indirect stimulation of the phagocytic mechanisms.

Acknowledgement The authors are grateful to Professor O. Sakaguchi, the. First Department of Hygienic Chemistry of this college, for supplying Staphylococcus aureus $\beta \mathrm{H} 248$ strain.

\section{References}

1) S. Gordon, J. Todd, and Z.A. Cohn, J. Exp. Med., 139, 1228 (1974).

2) a) E.F. Osserman, M. Klockars, J. Halper, and R.E. Fischel, Nature (London), 243, 331 (1973); b) M. Klockars and P. Roberts, Acta Haemat., 55, 289 (1976).

3) a) G.A. Currie and S.A. Eccles, Br.J. Cancer, 33, 51 (1976); b) N.R. DiLuzio, J. Reticuloendothel. Soc., 26, 67 (1979).

4) a) C. Adlam, E.S. Broughton, and M.T. Scott, Nature New Biol., 235, 219 (1972); b) N.A. Sher, S.D. Chaparas, L.E. Greenberg, and S. Bernard, Infect. Immun., 12, 1325 (1975). 
5) N.R. DiLuzio, and D.L. Williams, Infect. Immun., 20, 804 (1978).

6) Y. Okawa, K. Hashimoto, and M. Suzuki, The 101st Annual Meeting of the Pharmaceutical Society of Japan, Kumamoto, April 1981, Abstract Paper p. 285.

7) Y. Okawa, M. Kadowaki, M. Suzuki, and S. Suzuki, Ann. Rep. Tohoku Coll. Pharm., 24, 113 (1977).

8) T. Nakamura, G. Tamura, and K. Arima, J. Ferment. Technol., 45, 869 (1967).

9) A.W. Devor, Anal. Chem., 24, 1626 (1948).

10) S. Gardell, Acta Chem. Scand., 7, 207 (1953).

11) B.N. Ames and D.T. Dubin, J. Biol. Chem., 235, 769 (1960).

12) V. Riveros-Moreno, R. Bomford, and M.T. Scott, J. Natl. Cancer Inst., 60, 653 (1978).

13) R.M. Parry, R.C. Chandan, and K.M. Shahani, Proc. Soc. Exp. Biol. Med., 119, 384 (1965).

14) G. Biozzi, B. Benacerraf, and B.N. Halpern, Brit. J. Exp. Pathol, 34, 441 (1953).

15) a) I. Azuma, E.E. Ribi, T.J. Meyer, and B. Zbar, J. Natl. Cancer Inst., 52, 95 (1974); b) I. Azuma, K. Sugimura, T. Taniyama, A.A. Aladin, and Y. Yamamura, Jpn. J. Microbiol., 19, 265 (1975).

16) a) W.D. Biggar and J.M. Sturgess, Infect. Immun., 16, 974 (1977); b) M.E. Selsted, and R.J. Martinez, ibid., 20, $782(1978)$.

17) J.G. Cappuccino, S. Winston, and G.C. Perri, Proc. Soc. Exp. Biol. Med., 116, 869 (1964). 